\title{
Critical Thinking as a Key Competency
}

\author{
Dana Petranová, Monika Hossová \\ Department of Media Education, Faculty of Mass Media Communication, University of Ss. Cyril and Methodius in Trnava, \\ J. Herdu 2, 91701 Trnava, Slovakia
}

\begin{abstract}
This paper focuses on the key competency of critical thinking and the perception of this competency as a basic building block of media literacy. It operates with the terms media education, media literacy, critical thinking and new media. It also covers the inclusion of media education in international documents. It focuses on the role of new media in the process of building critical thinking competency and on technical methods that reinforce this competency. The aim of the paper is to emphasize the urgent need to form the critical thinking competency and analyse the possibilities of raising the media literacy and critical thinking by implementing new media and communication technologies into teaching. The paper analyses also the possibilities of using the activating methods in the teaching process.
\end{abstract}

Index terms - critical thinking, media literacy, media education, new media, teaching methods.

\section{Introduction, Characteristics of Basic Terms}

Society now places a tremendous amount of emphasis on media literacy; the objective of related educational curriculum and academic programs is on increasing such literacy and media education. Given the fact that this trend is closely related, in particular, to the vast quantity of media content that is produced and that has become a part of everyday life, such content influences people and changes their opinions and attitudes, changing the value systems and behaviour of people. The tremendous influence of media and media content on people does not have to be eliminated; however, everyone must be capable of processing this content, examining such content in a critical manner and decoding this content while analysing its intentions, influences and stereotypes in order to recognise the manner in which it functions, etc. This indicates the need for media education and, therefore, the need to increase media literacy among all groups in the population.

Media education is a long-term educational process in which individuals acquire media knowledge and increase their awareness of the influences, functions and roles of media. Individuals learn how to assess and create media content in this process, thereby increasing their media literacy and developing their mental competencies [1]. Media literacy is the ability to process media content and to analyse it. This includes looking critically at media content, understanding the functions of media and their standing in democratic society and the conditions required for their existence and functionality [2]. Media competencies can then be considered the highest level of media literacy, comprising a set of knowledge, abilities and skills that individuals acquire during the media education process [3]. Media competencies are also characterised as competencies that help one understand media, their structure, creation and influence. Having media competencies allows individuals to deliberately use media and their contents and to share in their creation [4].

Critical thinking is a key competency and a building block for media competencies. Critical thinking is, essentially, independent, analytical and unbiased thinking whereby an individual takes a critical view of media content, mediaproduced information and media themselves. This includes the ability of an individual to analyse content, select important facts and information and contemplate their significance, hidden agendas and the intentions of the media content they consume. Developed critical thinking skills facilitate the perception and separation of reality from media reality and someone thinking critically approaches information in a critical manner, looking for causes and evidence while exposing stereotypes and foreseeing consequences [5]. In this context Petranová and Burianová stress the need to form the critical thinking competency with children and youth (even with seniors) as it is them who often do not differentiate between real and media reality [6].

Operating with information and knowledge gleaned from content is a characteristic trait of critical thinking. A person who naturally thinks critically doubts this information and searches for logical context and order while arguing with the content. The resulting information is more than simply consumed; rather it is incorporated into the individual's existing bank of information and knowledge for use in the future. Some of the differences between non-critical and critical thinking are summarised in Table 1 - Comparison of non-critical and critical thinking [7].

TABLE I Comparison of non-critical and critical thinking

\begin{tabular}{|l|l|}
\hline Non-critical thinking & Critical thinking \\
\hline passive & active \\
\hline $\begin{array}{l}\text { superficial investigation, } \\
\text { consumption of } \\
\text { information }\end{array}$ & $\begin{array}{l}\text { in-depth investigation, gets beneath the } \\
\text { surface and looks for connections }\end{array}$ \\
\hline $\begin{array}{l}\text { consumption of existing } \\
\text { information and } \\
\text { knowledge }\end{array}$ & $\begin{array}{l}\text { independent thinking, derivation of one's } \\
\text { own knowledge }\end{array}$ \\
\hline dogmatic, unconscious & logical, conscious and reasoned \\
\hline assumption & postulation, hypothesis \\
\hline
\end{tabular}

\section{Approaches to Media Education and Media Literacy}

Media education and critical thinking have gradually become integrated into the educational systems in many countries since the 20th century. Increasing media literacy and the need for critical thinking skills has become a vital and a 
mandatory requirement for all. The addition of media education into the education system became the subject of initiatives and supporting activities in individual countries and their legislative frameworks. There are many initiatives supporting the development of media literacy in Europe as well. Informal activities, education and organisations in these areas are also important and focus on including media education in the school-based, formal system of education, school curriculum and the creation of academic programs focused on this very topic at the university level [8].

Four models of media education have been developed from the individual countries in which media education is widespread and deeply embedded in the education system: the Canadian model, the US model, the Latin American model and the Australian model [9].

The Canadian media education model is primarily focused on the development of critical thinking skills and active citizenship. The basic points of this media education model are preparation for living with media, critical analysis of media content and exposing stereotypes and mechanisms. It focuses on the issues of globalisation and the existence of new communication technologies. Learners learn how to understand the significance and meaning of media products and how to spot the commercial interests of media, societal and political factors at work in media, etc. The media education model in the United States is focused more on violence and sex in media. Primary traits of the system include cooperation and partnership, noticing stereotypes and differences related to multiculturalism and emphasises the need for critical thinking competency. The Australian media education model is focused on protecting minorities and the perception of media as a type of art that plays a role in various parts of human life. The Australian media education model also includes the four resources model of critical literacy according to Luke and Freebody. Ref. [8] states that this model is focused specifically on critical literacy and contains four areas, coding competence, semantic competence, pragmatic competence and critical competence. Through these individual competencies, learners are taught how to decipher text, determine the process employed by the author, what to do with the text and what others should do with the type, the cultural factors behind the text that must be considered, the different ways in which the text could be interpreted, the intentions for publishing the text, the blatant and hidden intentions of the text, etc. The critical literacy model provided by Luke and Freebody provides a kind of progressive guide for thinking critically about a text.

Media education has developed extensively in the Europe in Great Britain. Education there is focused on the audio-visual aspects of media, but does emphasise the need to approach techniques, procedures and conventions in a critical manner. It also emphasises the need to assess media content and to doubt or avoid unsuitable content.

European society is visibly taking the initiative with respect to questions of increasing media literacy, which includes the existence of a legislative framework for media education. Ref. [1] refers to a number of these initiatives and activities. UNESCO has long focused on this issue and one tangible result is the Grünwald Declaration from 1982. This Declaration cements the need to support the development of critical thinking amount people and expresses the need to include media education into the life-long education process. Another initiative to introduce critical thinking as a key competency is Recommendation 1466 (2000) on Media Education issued by the Council of Europe. Critical thinking is contained in the core of media education as practical instruction in which an individual learns to take a critical stance towards media. Similarly the European Commission's COM (2007) 833 on A European approach to media literacy in the digital environment defines media literacy as ability to access media and to understand and critically evaluate different aspects of media and media contents. Ref. [7] refers to actual criteria used to assess media levels (Study Assessment Criteria for Media Literacy Levels, 2009-2010). This study evaluates the level of media literacy at the level of environmental factors and individual competencies. Critical thinking is one of the essential competencies and combines understanding media content and its operation, knowledge about media and media regulation and user behaviour.

Critical thinking is more than just a current topic of discussion within the topic of media education. Critical thinking has been seen as a key competency from the very beginning of the spread of media education and is included in documents and contained in legislative frameworks and models. The development of this competency was, and continues to be, perceived as mandatory and one of the basic prerequisites for the development of media literacy.

\section{Critical Thinking, New Media and Activating Teaching Methods}

In the context of the above, focus must be devoted on developing critical thinking in school-based education or in education in general. School-based (i.e. formal, institutionalised) education seeks to develop independent and critical thinking skills among students, the same as media education. Schools focus their attention and students, while the traditional role held by teachers of simply delivering information has progressively transformed into that of a coordinator and adviser. This role has expanded to include delivering information that students dogmatically consume to include teaching them to think critically and independently through teaching and in the process of delivering such information.

In turn, the teacher's attention on the student and gradual implementation of media education into all areas of life, including school-based education, is also connected to the implementation of information and communication technologies and new media into education. Information and communication technologies support education as they involve the acquisition and exchange of information. New media, as a mass of applications and on-line projects, use the Internet in order to function and the Internet is also used in the 
educational process, during time at school and by students when doing homework. Publication platforms (Wordpress) and blogs, cooperative platforms (Wikipedia), platforms to improve productivity (GoogleDocs) and platforms to share different types of content (YouTube, iTunes) show the utility of new media in the educational and teaching process [10].

The Internet opens up new opportunities for students to work independently, to seek out new information and interesting subjects and to find various aids. A tremendous number of educational websites, videos and presentations (which are also offered by Wikipedia and YouTube) are available. This represents a potential teachers can exploit within their teaching, while students can use these resources within their preparations for receiving teaching. In addition to making learning more attractive, the Internet and new media support the ability of students to work independently, select information, choose relevant sources and verify information, and therefore use critical thinking. Critical thinking then becomes one of the basic competencies that everyone should possess in order to ensure their full integration and functionality within society.

In addition to leading students towards independent critical and analytical thinking, it is important to remember the risks associated with the use of the Internet and new communication technologies. Evaluating and taking a critical view of media content involves the actual selection of new media, which should be just as critical. Wiki pages are a good example of cooperative platforms, a type of new media. The variety available is tremendous; while the most well-known is Wikipedia (others include Scholarpedia, PBWorks and Wikimedia). These pages function as public encyclopaedias, their contents are modifiable (the currently available article may not be the work of the original author) and the information that is published may not be verified or relevant, which is not the case with textbooks and other academic texts. The example of these cooperative platforms demonstrates the need to verify available information from a number of different sources and the need to take a critical approach to information and the source itself. It's important to note the fact that new media should not be viewed in a negative light, even given this example. Their benefits are based on an attractive form of teaching and the potential they represent for innovating teaching and educational processes. The use of new media and information and communication technologies is inherently beneficial as well, which is why the application of a critical approach towards them can help develop and sustain the important competency of critical thinking.

New media and information and communication technologies in education support the competency of critical thinking as they are different from standard teaching methods; simply put they are a new and more attractive method that activates students. Standard teaching methods can be considered to be passive consumption of existing knowledge and information provided by the teacher. This approaches the characteristics of non-critical thinking. Activating methods actively engage students and lead to more in-depth analysis of the given issue and the derivation of conclusions. Students think independently and therefore critically.

According to Ref. [9], activating methods are understood to be teaching methods that place emphasis on thinking and solving problems, where the educational and teaching goals are primarily achieved by the learning work of the students themselves. Cinquain is a well-known method, where students summarise the information, opinions or attitudes they have learned using a few words (into poems or five-line constructs). Conceptual maps are widely used and in such maps students graphically depict knowledge, terms and relationships between them. Students use the insertion method (using a set of four characters) to indicate if the information provided by a text was something they had learned before, something new, if it corrected existing information or if they want to learn more amount the information from the text. The paired reading method focuses on two students in a pair, where one reads the text and presents while the other reads the text, listens to the presentation and then asks questions about the text. The threephase EUR learning model begins with students actively dealing with the information they already have on a specific topic (evocation), adding information to their memory (awareness of meaning) and finally mastering the material, acquiring permanent knowledge while students share opinions and thoughts with one another on the given topic (implementation). Other important activating methods, in addition to those above, include the game "memory", mixed events, work with written texts, analyses of semantic elements, the Socratic Method and Venn diagrams.

Activating teaching methods open up the opportunity to use new media in education. Methods such as cinquain and conceptual (mental) maps can draw on information from new media and the Internet and may inherently contain information directly related to media education and related problems and the competency of critical thinking. The use of the paired reading method in combination with the use of cooperation platforms (e.g. Wikipedia) focuses on reading with comparison and then raising questions, but may also table the issue of the relevance of available information, forcing students to verify the information and to investigate its context in more depth. In this example the combination of activating teaching methods with the use of new media, which supports the development of media literacy as well, is clear. By confronting this issue, students gain knowledge that helps support their critical thinking and causes them to consider the need to have this competency available. Direct confrontations with examples demonstrating these issues and real experience related from a lack of competency in the area of taking a critical approach to media and media content may also be of benefit in this area. Awareness of existing risks associated with the use of media and new communication technologies leads students to the awareness of the need for education in this area and, moreover, work involving lessons from real events can help bring students closer to the teaching process and material, making them more attractive and easier to remember. 
Given this, it is critical to be aware of the need for a high level of media literacy among teachers, who have the important task of teaching students to increase their general and media literacy. Increasing media literacy and the need for media education in life-long education has come into its own. The previously-mentioned Grünwald Declaration on media education considers the introduction of media and information literacy to be an integral part of life-long education. Ref. [1] references Recommendation 1466 (2000) on Media Education, which emphasises that media education should be focused on adults in the present and in the future and therefore should be a part of life-long education. The recommendation to integrate media education as a part of life-long education into school curriculum was based on the completed Study Assessment Criteria for Media Literacy Levels.

Media education has permeated into formal, school-based education and critical thinking is seen as a core competency. Given the gradual spread of media education and the mentioned new communication technologies across society as a whole, individuals have been faced with the new challenge of quickly adapting to the new communication environment. Nataša Slavíková mentions the term on-line digital immigrants as people who have integrated various aspects of these new technologies in their lives, thereby adapting to the modern world. In this context, cases are cited where helpless teachers are forced to align their lives with the media experiences of the children they are teaching [11]. This opens up another serious problem, teacher qualifications are just not sufficient and some teachers have not yet adapted to modern trends in teaching. Cases have appeared where teachers completely ignore these trends and recommendations and do not adapt their teaching to the needs of society, do not implement new communication technologies, do not deal with the issue of media education as a cross-cutting theme while teaching, etc. The need to introduce media education into university-level education is a logical extension in this case for programmes involving education, teaching, work with young people (social work, etc.), media and other social sciences and humanities. Media education should permeate into society from the bottom up, from learning at home to formal school-based education, and in a top down manner, beginning with the education of future teachers and professionals in educational fields and preparing them for life with media in a broader sense of the term. Media education today is a part of curriculum, formal education and even informal education, all of which take place in various institutions, organisations and associations. Focus within formal education should involve all of its levels: pre-primary, primary, secondary and higher secondary education. Some Slovak schools include media education as a cross-cutting theme in selected subjects, while others have classified it as a separate subject. Media education in Slovakia also figures into life-long education and initiatives focused on increasing media literacy have been developed on the basis of this concept. A significant step was the accreditation of an academic programme of Applied Media Studies at the Faculty of Mass Media Communication at University of Ss. Cyril and
Methodius, which focuses on teaching media education to future media professionals, instructors and teachers. The IMEC - International Media Education Centre - is also active at the faculty and connects media education initiatives in Slovakia and implements educational activities in this field. It offers educational options for educational professionals, works on a concept for including media education into the education system and its members focus on teaching media education and initiate other activities as needed to spread media literacy. It is important to be aware of the critical need for education in this area during life-long education, the need to adapt to the latest trends and, in the case of teachers in particular, the need to implement the trends into the educational process so that media education can achieve its intended objectives.

\section{Conclusion}

Critical thinking is a basic competency of media education, which emphasises the need to ask questions, to be able to identify relevant sources of information, to verify such sources and to obtain valuable information [12].

The importance of critical thinking can currently be seen in all phases of life, not just in connection with the use of media and new information and communication technologies. Media education and activities focused on increasing media literacy create the space needed for the development of critical thinking and other competencies that prepare learners to live with media. Critical thinking and media education as such have even become objects of interest in teaching religion at schools as they are aware of the current media influence and the need to educate pupils in this area [13].

The need for media and information literacy has become more acute with the rise of new media and the infiltration of information and communication technologies into everyday life. The idea of implementing new media into the educational process at all levels of education may also prove beneficial as it improves the ability of individuals to work with such media (e.g. computer literacy) and their critical thinking competencies. The way forward towards increasing the level of media literacy includes the implementation of activating teaching methods into such education; however, emphasis must remain on the emerging need to reform the system through which educators and other education professionals are trained so that media education with focus on increasing media literacy permeates throughout society so that critical thinking can become a key and given competency available to everyone.

\section{Acknowledgement}

This article was supported by the Slovak Research and Development Agency under the contract No. APVV-0754-12.

\section{References}

[1] D. Petranová, Mediálna gramotnost' seniorov (Media Literacy of Seniors), Trnava: UCM, 2013, p.15.

[2] A. Grizzle and C. Wilson, Media and Information Literacy Curriculum for Teachers, Paris: UNESCO, 2011, p.18.

[3] D. Buckingham, Media education: literacy, learning and contemporary culture, Cambridge: Polity Press, 2003, 232 pp. 
[4] V. Kačinová, "Terminological problems of media education," Communication Today, vol. 3, no. 2, pp.24-39, 2012.

[5] D. Petranová, "Mediálna výchova," Lexikón masmediálnych štúdii ("Media Education". Lexicon of Mass Media Studies), Trnava: FMK UCM, 2011, p.403.

[6] D. Petranová and L'. Burianová, "Importance and role of new media in the process of media literacy education," SGEM 2014 International Multidisciplinary Scientific Conferences on Social Sciences and Arts, vol. 2. pp. 389-398, 2014.

[7] D. Petranová, "Does media education at schools develop students' critical competences? ," Communication Today, vol. 2, no. 1, pp.66-83, 2011.

[8] D. Petranová, Mediálna výchova a kritické myslenie (Media Education and Critical Thinking), Trnava: UCM, 2013, pp.35-36.
[9] P.C. Rivoltella, "Media education. Modelli, esperienze profilo disciplinare," in Mediálna výchova a kritické myslenie, D. Petranová, Trnava: UCM, 2013, pp.36-45, 82-87.

[10] N. Vrabec, "Sociálne médiá," Lexikón masmediálnych štúdii ("Social Media". Lexicon of Mass Media Studies), Trnava FMK UCM, 2011, pp.436-437.

[11] N. Slavíková, "Význam mediálnej výchovy v prvej dekáde 21.storočia" ("Importance of Media Education in the First Decade of the 21st Century"), Communication Today, vol. 1, no. 1, pp.30-42, 2010.

[12] A. Plencner, "Critical thinking and the challenges of internet," Communication Today, vol. 5, no. 2, pp.4-18, 2014.

[13] N. Vrabec, P. Polievková and M.Moravčíková, "The role of media literacy development as a part of religious education curriculum," European Journal of Science and Theology, vol. 9, no. 5, pp.211-223, 2013. 